\title{
Morphological Studies on the Bone and Cartilage of Laboratory Animals
}

\author{
Kanji YAMASAKI \\ Chemical Inspection and Testing Institute, Hita Research Laboratory, \\ 3-822 Ishii, Hita-shi, Oita 877, Japan
}

Contents
I. Introduction
II. Bone and cartilage lesions
1. Degenerative osteoarthrosis in rats and mice
2. Osteosclerosis in rats and mice
3. Renal osteodystrophy in rats and mice
4. Regressive epiphyseal cartilage changes in rats
5. Aseptic bone necrosis in mice

\section{I . Introduction}

The morphological changes that occur in various organs of rats and mice have become apparent from the results of many safety studies. However, spontaneous bone and cartilage lesions in these animals have not been studied thoroughly. Therefore, a morphological study of the bone and cartilage of rats and mice was performed, and degenerative osteoarthrosis, osteosclerosis, renal osteodystrophy, regressive epiphyseal cartilage changes and aseptic bone necrosis were observed.

\section{Bone and cartilage lesions}

1. Degenerative osteoarthrosis in rats and mice $[39,48]$

Degenerative osteoarthrosis occurring in large or small synovial joints has been described in humans $[6,13,30]$, domestic animals $[29,35,37,41,47]$ and fowls $[29,43]$, although this disorder has not been investigated thoroughly in rats and mice [24-29]. The pathological findings of degenerative osteoarthrosis that occur in these animals are described below.

Rat: A total of 20 male Sprague-Dawley rats (Clea Japan Inc., Tokyo, Japan) were studied at 6 and 12 months of age. They all appeared to be healthy and had no clinical or hematological abnormalities. The femur and patella from each rat were examined. No gross abnormalities were detected, but histological changes were observed in the femur at 12 months and patella at 6 and 12 months of age (Table 1). The initial change was a loss of matrix homogeneity, which progressed with increasing age and was accompanied by chondrocyte degeneration and necrosis. Furthermore, at 12 months of age, focal areas in the femur had been destroyed, resulting in a roughened surface (Fig.1), the chondrocytes showed diffuse proliferation and were present in groups in the femoral radial zone, and marginal chondrophytes were observed in the patella. There were no essential histochemical differences between the femurs and patellas examined in this study. In 6-month-old rats, the transitional and radial zones reacted positively with toluidine blue (TB, pH 4.1) (Table 2). The transitional zone showed reduced $\mathrm{TB}(\mathrm{pH} 4.1)$ reactivity with increasing age, whereas the radial zone exhibited increased local reactivity. The TB $(\mathrm{pH} 4.1)$ reactivities of the territorial and interterritorial areas in the tran- 
Table 1. Summary of histological changes in the articular cartilage of the femur and patella

\begin{tabular}{|c|c|c|c|}
\hline Bone & Zone & 6 months of age & 12 months of age \\
\hline \multirow[t]{3}{*}{ Femur } & Tangential zone & Normal & $\begin{array}{l}\text { Loosening of the matrix } \\
\text { Degeneration and necrosis of chondrocytes } \\
\text { Erosion }\end{array}$ \\
\hline & Transitional zone & Normal & $\begin{array}{l}\text { Loosening of the matrix } \\
\text { Degeneration and necrosis of chondrocytes }\end{array}$ \\
\hline & Radial zone & Normal & $\begin{array}{l}\text { Loosening of the matrix } \\
\text { Degeneration and necrosis of chondrocytes } \\
\text { Proliferation of chondrocytes }\end{array}$ \\
\hline \multirow[t]{3}{*}{ Patella } & Tangential zone & Loosening of the matrix & $\begin{array}{l}\text { Loosening of the matrix } \\
\text { Degeneration and necrosis of chondrocytes }\end{array}$ \\
\hline & Transitional zone & Loosening of the matrix & $\begin{array}{l}\text { Loosening of the matrix } \\
\text { Degeneration and necrosis of chondrocytes }\end{array}$ \\
\hline & Radial zone & Loosening of the matrix & $\begin{array}{l}\text { Loosening of the matrix } \\
\text { Degeneration and necrosis of chondrocytes } \\
\text { Marginal chondrophyte }\end{array}$ \\
\hline
\end{tabular}

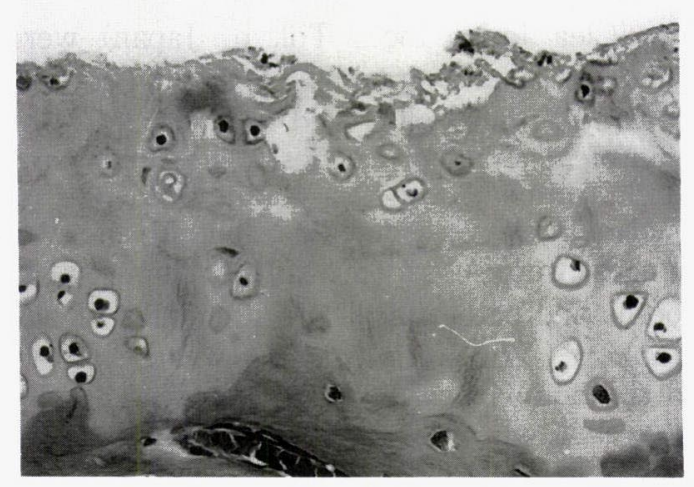

Fig. 1. Articular cartilage in femur from a 12-month -old male rat Erosion and roughening of the cartilage matrix $\mathrm{HE} \times 200$

sitional zone did not differ significantly, but the territorial area in the radial zone showed a more marked reaction than the interterritorial area. At 6 and 12 months of age, the transitional and radial zones reacted weakly with $\mathrm{TB}$ ( $\mathrm{pH} 2.5$ ) but reacted positively with alcian blue ( $\mathrm{AB}, \mathrm{pH} 1.0$ ) in the presence of $0.9 \mathrm{M} \mathrm{MgCl}_{2}$. All the zones reacted well with periodic acid Schiff (PAS), but this reactivity lessened with increasing age. The femoral area that was surrounded by erosion at 12 months of age failed to react with TB ( $\mathrm{pH} 2.5$ and 4.1), AB ( $\mathrm{pH} 1.0$ ) with $0.9 \mathrm{M} \mathrm{MgCl}_{2}$ or PAS. However, the area of proliferated chondrocytes in the femoral radial zone of 12-month-old rats did react with $\mathrm{TB}(\mathrm{pH} 2.5$ and 4.1$)$ and $\mathrm{AB}(\mathrm{pH}$ 1.0) with $0.9 \mathrm{M} \mathrm{MgCl}_{2}$. In enzyme digestion experiments, the tangential zone at 6 and 12 months of age had no TB $(\mathrm{pH} 4.1)$-positive matrix that was digestible by testicular hyaluronidase, whereas the interterritorial area of the transitional zone and the territorial and interterritorial areas of the tradial zone had weakly positive matrices. Treatment with Streptomyces hyaluronidase and chondroitinase $\mathrm{ABC}$ revealed $\mathrm{TB}$ ( $\mathrm{pH} 4.1$ )-positive matrices in the transitional and radial zones at 6 and 12 months of age. The TB ( $\mathrm{pH} 4.1)$ reactivity with Streptomyces hyaluronidase and chondroitinase $A B C$ at 6 and 12 months of age declined markedly in both the territorial and interterritorial areas compared with control (enzyme untreated) samples. In the femoral proliferated chondrocytic and patellar marginal chondrocytic areas, the territorial and interterritorial areas reacted weakly with TB $(\mathrm{pH} 4.1)$ after treatment with testicular hyaluronidase and Streptomyces hyaluronidase and reacted more markedly after treatment with chondroitinase $\mathrm{ABC}$ than untreated control samples.

The histological and histochemical changes in the articular cartilage were essentially the same as those in the femur and patella. In this study, the articular cartilage contained hyaluronic acid (HA), chondroitin sulfate A and/or C (ChS A/C) and keratan sulfate (KS). The HA 
Table 2. Histochemical reactions of the articular cartilage of the femur

\begin{tabular}{|c|c|c|c|c|c|c|}
\hline \multirow[b]{2}{*}{ Staining procedures } & \multicolumn{3}{|c|}{6 months of age } & \multicolumn{3}{|c|}{12 months of age } \\
\hline & $\begin{array}{l}\text { Tangential } \\
\text { zone }\end{array}$ & $\begin{array}{l}\text { Transitional } \\
\text { zone }\end{array}$ & $\begin{array}{l}\text { Radial } \\
\text { zone }\end{array}$ & $\begin{array}{l}\text { Tangential } \\
\text { zone }\end{array}$ & $\begin{array}{l}\text { Transitional } \\
\text { zone }\end{array}$ & $\begin{array}{l}\text { Radial } \\
\text { zone }\end{array}$ \\
\hline \multicolumn{7}{|l|}{ a. Single stainings } \\
\hline $\mathrm{TB}(\mathrm{pH} 4.1)$ & $0-1 \mathrm{~B}$ & $1-2 B$ & $1-2 B$ & $0-1 \mathrm{~B}$ & $0-1 \mathrm{~B}$ & $1-3 \mathrm{~B}$ \\
\hline $\mathrm{TB}(\mathrm{pH} 2.5)$ & 0 & $0-1 \mathrm{~B}$ & $0-1 \mathrm{~B}$ & 0 & $1 \mathrm{~B}$ & $1 \mathrm{~B}$ \\
\hline $\mathrm{AB}(\mathrm{pH} 1.0)$ with $0.9 \mathrm{M} \mathrm{MgCl}_{2}$ & 0 & $1 \mathrm{~B}$ & $1-2 B$ & 0 & $1 \mathrm{~B}$ & $1-2 \mathrm{~B}$ \\
\hline PAS & $2-30 \mathrm{R}$ & $2-30 \mathrm{R}$ & $2-30 \mathrm{R}$ & $1-20 \mathrm{R}$ & $1-20 \mathrm{R}$ & $1-20 \mathrm{R}$ \\
\hline \multicolumn{7}{|l|}{ b. Enzyme digestion } \\
\hline Testicular hyaluronidase- $\mathrm{TB}(\mathrm{pH} 4.1)$ & 0 & $0-1 \mathrm{~B}$ & $0-1 \mathrm{~B}$ & 0 & $0-1 \mathrm{~B}$ & $1 \mathrm{~B}$ \\
\hline Streptomyces hyaluronidase-TB ( $\mathrm{pH} 4.1)$ & 0 & $1-2 \mathrm{~B}$ & $0-2 B$ & 0 & $0-1 \mathrm{~B}$ & $1-2 \mathrm{~B}$ \\
\hline Chondroitinase ABC-TB (pH 4.1) & 0 & $1 \mathrm{~B}$ & $1-2 B$ & 0 & $0-1 B$ & $1-2 \mathrm{~B}$ \\
\hline
\end{tabular}

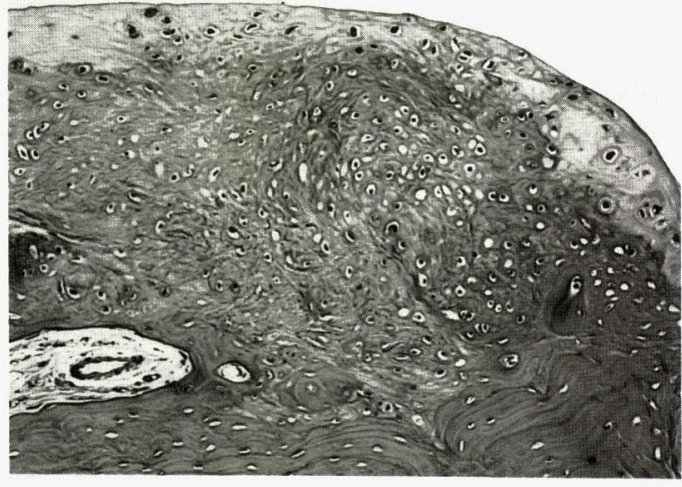

Fig. 2. Articular cartilage in tibia from a 665-day-old male mouse. Note the degeneration and necrosis of articular cartilage associated with abnormal proliferation of subchondral bone. $\mathrm{HE} \times 100$

and $\mathrm{ChS} \mathrm{A} / \mathrm{C}$ were located in the territorial and interterritorial areas of the transitional and radial zones, where KS also was prominent. Therefore, glycosaminoglycans (GAGs) were found mainly in the transitional and radial zones, indicating that these zones are active in cartilage metabolism. Reduction of GAG levels was conspicuous in the area surrounding the erosions. The GAGs play a major role in the retention of water within the tissue, thus endowing the cartilage with resilience against compression forces [4]. If mechanical loading were to be imposed on articuli in which GAG levels were decreased, then erosion would occur easily. Decreased GAG levels were observed in the articular cartilage, even in the absence of histological changes, and this decrease progressed with increasing age. The reduction in GAG levels is reckoned to be an important cause of degenerative osteoarthrosis.

Mouse : A total of 117 ICR mice (56 males and 61 females, Charles River Japan Inc., Kanagawa, Japan) were used in this experiment. The tibia from each animal was examined histologically to gain further information about degenerative osteoarthrosis. The major gross changes observed were roughening of the articular surface, narrowing or focal thickening of the articular cartilage and osteophytes at the joint margins. The histological changes comprised matrix loosening, erosion, marginal osteophytes in the articular cartilage and subchondral bone sclerotic changes (Fig.2). These changes were particularly marked near the ligament insertions. Furthermore, the severity of the lesions was greater in males than females less than 500 days old, but almost the same in both sexes after this age (Table 3).

These results show clearly that the incidence of the lesions increased with increasing age, indicating that aging plays an important role in the development of degenerative osteoarthrosis. It should be emphasized that the incidence and progress of this disease in mice varies a great deal with the strain [29]. Furthermore, some strains show quite different incidences of these lesions according to sex [24,27-29]. The ICR mice used showed a high incidence of lesions irrespective of sex. Therefore, this strain may prove to be an invaluable 
Table 3. Incidence of microscopic changes in joints of the tibia

\begin{tabular}{|c|c|c|c|c|c|c|}
\hline \multirow{2}{*}{$\begin{array}{l}\text { Lesions } \\
\text { Sex }\end{array}$} & \multicolumn{6}{|c|}{ Incidence of lesion at different ages } \\
\hline & Age (days) & $<500$ & $500-600$ & $600-700$ & $700<$ & Total \\
\hline \multicolumn{7}{|c|}{ Degeneration } \\
\hline Male & & $11 / 11(100)^{a}$ & $8 / 8(100)$ & 9/9 (100) & $28 / 28(100)$ & $56 / 56(100)$ \\
\hline Female & & $5 / 5 \quad(100)$ & $7 / 7(100)$ & $16 / 16(100)$ & $33 / 33(100)$ & $61 / 61(100)$ \\
\hline \multicolumn{7}{|l|}{ Erosion } \\
\hline Male & & $6 / 11(55)$ & $8 / 8(100)$ & $9 / 9(100)$ & $28 / 28(100)$ & $51 / 56(91)$ \\
\hline Female & & $2 / 5(40)$ & $7 / 7(100)$ & $16 / 16(100)$ & $33 / 33(100)$ & $58 / 61(95)$ \\
\hline \multicolumn{7}{|c|}{ Marginal osteophyte } \\
\hline Male & & $3 / 11(27)$ & $2 / 8(25)$ & $3 / 9(33)$ & $12 / 28(43)$ & $20 / 56(36)$ \\
\hline Female & & $0 / 5(0)$ & $4 / 7(57)$ & $5 / 16(31)$ & $8 / 33(24)$ & $17 / 61(28)$ \\
\hline \multicolumn{7}{|l|}{ Eburnation } \\
\hline Male & & $5 / 11(45)$ & $7 / 8(88)$ & $7 / 9(78)$ & $28 / 28(100)$ & $47 / 56(84)$ \\
\hline Female & & $1 / 5(20)$ & $6 / 7(86)$ & $16 / 16(100)$ & $33 / 33(100)$ & $56 / 61(92)$ \\
\hline
\end{tabular}

a Number affected/Number examined $(\%)$

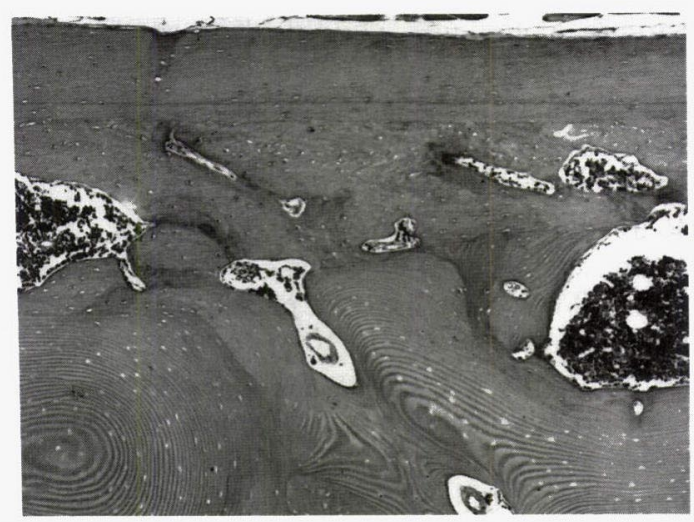

Fig. 3. Tibia from a 30-month-old female rat Replacement of the marrow cavity by newly formed lamellar bone $\mathrm{HE} \times 40$

model for the study of joint disease.

2. Osteosclerosis $[44,46]$

Osteosclerosis, which is characterized by an increase in the volume of mature bone per unit volume in the marrow space, has rarely been described in laboratory animals [11]. The morphological changes of this condition in rats and mice are described below .

Rat: A total of 90 Fischer 344 rats (Charles River Japan Inc., Kanagawa, Japan), which appeared to be healthy and had no clinical or hematological abnormalities, were studied ( 15 males and 15 females each at the ages of 6,18 and 30 months). Gross examination showed that the affected bones had variable amounts of osseous trabeculae in the marrow cavities, and microscopic examination of the tibias revealed abnormal endosteal osteogenesis, which resulted in osteosclerosis. The initial change involved focal proliferation of fibrous connective tissue with osteoid seams on the marrow surface of the cortical bone and bone traeculae. As the lesions progressed, newly formed immature or mature bone was deposited. In the advanced lesions, the marrow cavity was occupied completely by lamellar bone, with marrow tissues scattered among it (Fig.3). Such osteosclerotic lesions were first seen in the tibia in 6-month-old females and 18-month-old males and became more severe with age (Table 4). The lesions in the females were more severe than those in the males. The sternal osteosclerotic lesions were essentially the same as those in the tibias. The changes were observed from 6 months of age in both sexes and became more pronounced with age, especially in the females. No significant changes were detected in the parathyroid glands, thyroid glands or ovaries.

Spontaneous osteosclerosis was observed in the cancellous bone of the tubular bones of 4 aged rats [17], and F 344 rats with mononuclear cell leukemia were reported to have a high incidence of osteosclerosis [34]. However, there are no reports about this disorder in clinically and hematologically normal rats. The bone lesions observed in the rats in this study were similar to those in aged and leukemic rats, and it should be noted that there was a high incidence of these bone lesions in both sexes. Furthermore, these osteosclerotic changes were observed first at 6 months of age 
Table 4. Incidence of severity of osteosclerosis in the tibia and sternum

\begin{tabular}{|c|c|c|c|c|c|c|c|c|}
\hline \multirow{2}{*}{ Sex } & \multirow{2}{*}{$\begin{array}{c}\text { Age } \\
\text { (months) }\end{array}$} & \multirow{2}{*}{$\begin{array}{l}\text { Number } \\
\text { examined }\end{array}$} & \multicolumn{3}{|c|}{ Tibia } & \multicolumn{3}{|c|}{ Sternum } \\
\hline & & & + & H & HI & + & H & H \\
\hline \multirow[t]{3}{*}{ Male } & 6 & 15 & $0^{\mathrm{a}}$ & 0 & 0 & 2 & 0 & 0 \\
\hline & 18 & 15 & 5 & 9 & 0 & 15 & 0 & 0 \\
\hline & 30 & 15 & 4 & 11 & 0 & 7 & 8 & 0 \\
\hline \multirow[t]{3}{*}{ Female } & 6 & 15 & 4 & 0 & 0 & 4 & 0 & 0 \\
\hline & 18 & 15 & 3 & 8 & 3 & 6 & 6 & 3 \\
\hline & 30 & 15 & 0 & 12 & 3 & 0 & 10 & 5 \\
\hline
\end{tabular}

+ ; mild $\quad+$; moderate $\quad H$; severe

a Number affected

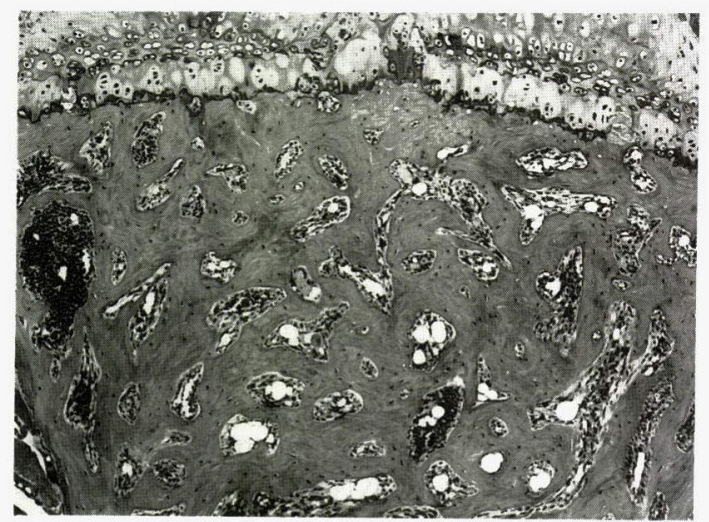

Fig. 4. Sternum from a 728-day-old female mouse Marrow cavity occupied by newly formed mature bone trabeculae $\mathrm{HE} \times 40$

and the incidence increased with age. Therefore, aging would appear to be one of the causative factors of this disorder.

Mouse : One hundred and sixty ICR mice ( 80 males and 80 females, Charles River Japan Inc., Kanagawa, Japan) were used in this study. Many died spontaneously and the rest (both sexes) were killed at 728 days of age. Overall, the age at death for the males ranged from 227 to 728 days and from 168 to 728 days for the females. On gross examination, hardness of the affected bones had increased and varying amounts of osseous trabeculae were observed in the marrow cavities compared with unaffected bones. The osteosclerotic changes were essentially the same as those in rats, although proliferation of osteogenic cells and osteoid seams were more severe (Fig.4). Furthermore, many osteoclasts associated with the changes described above were detected.
The femoral and sternal histological changes were essentially the same. The sternal osteosclerotic lesions occurred in male mice older than 350 days and in females in excess of 300 days of age ; the total incidences were $86 \%$ and $90 \%$, respectively (Table 5 ). The tibial changes were observed in both sexes after 350 days of age, and the total incidence was $82 \%$ in the males and $79 \%$ in the females. The lesions were more severe in the females than the males. No significant lesions related to the bone changes were detected in any other organs, including the endocrine system.

Overall, the osteosclerotic changes observed in mice were essentially the same as those in rats, although proliferation of osteogenic cells with osteoclasts was more pronounced than that in rats. Experimental osteosclerotic lesions have been induced in mice and dogs by administering estrogenic hormones $[12,28,33]$ and in rats and rabbits by calcitonin injections $[32,36]$. Almost identical changes to those observed, namely focal fibro-osseous lesions with occasional bone trabeculae, were observed in the sternum and long bones from 99 of 228 aged female mice and in only 1 of 226 males [23]. The cause of these lesions was suggested to be a hormonal disturbance, as there was a relatively high incidence of ovarian cysts and uterine cystic adenomatoid hyperplasia. However, no such lesions related to the bone lesions in the female mice were observed in this study, and, furthermore, it should be noted that the incidence of these lesions was high in both sexes and they became more severe with increasing age.

3 . Renal osteodystrophy $[38,40]$

A syndrome involving a combination of severe renal failure, hyperparathyroidism and bone lesions, known as renal osteodystrophy, has been reported in dogs $[1,3,14]$, cats $[1]$ and rats $[15,17]$. The following sequence is considered to be the primary pathogenetic mechanism of this disorder [15] : severe renal failure $\rightarrow$ hyperphosphatemia $\rightarrow$ hypocalcemia $\rightarrow$ secondary hyperparathyroidism $\rightarrow$ osteodystrophy.

Mouse : There are no reports that describe renal osteodystrophy in mice. On histological examination, renal osteodystrophy was found in eight males and 11 females among the 370 male and 370 female ICR mice (Charles River 
Table 5. Incidence of osteosclerosis in the sternum and tibia at different ages

\begin{tabular}{|c|c|c|c|c|c|c|}
\hline \multirow{2}{*}{$\begin{array}{l}\text { Bone } \\
\text { Sex }\end{array}$} & \multicolumn{6}{|c|}{ Incidence of lesion at different ages } \\
\hline & Age (days) & $<300$ & $300-400$ & $400-500$ & $500<$ & Total \\
\hline \multicolumn{7}{|l|}{ Sternum } \\
\hline Male & & $0 / 6(0)^{a}$ & $8 / 12(67)$ & $7 / 7(100)$ & $54 / 55(98)$ & $69 / 80(86)$ \\
\hline Female & & $1 / 6(17)$ & $10 / 11(91)$ & $3 / 4(75)$ & $58 / 59(98)$ & $72 / 80(90)$ \\
\hline \multicolumn{7}{|l|}{ Tibia } \\
\hline Male & & $0 / 6(0)$ & $4 / 9(44)$ & $6 / 7(86)$ & $52 / 54(96)$ & $62 / 76(82)$ \\
\hline Female & & $0 / 6(0)$ & $4 / 6(67)$ & $2 / 4(50)$ & $52 / 57(91)$ & $58 / 73(79)$ \\
\hline
\end{tabular}

a Number affected/Number examined (\%)

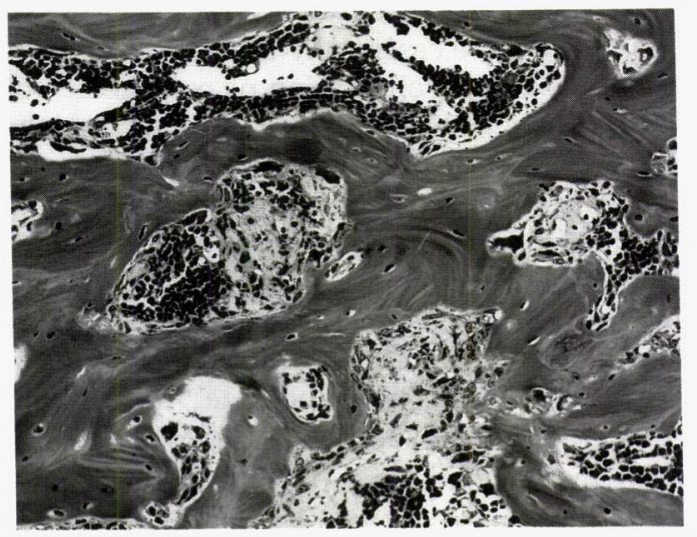

Fig. 5. Femur from a 728-day-old male rat Areas of bone resorption by osteoclasts associated with proliferation of fibrous connective tissue and osteoid seams $\mathrm{HE} \times 125$

Japan Inc., Kanagawa, Japan) examined. Fourteen of these 19 animals died spontaneously and 5 were killed; the age at death for the males ranged from 451 to 728 days and for the females 302 to 728 days. The femur and sternum from each mouse were examined. No macroscopic abnormalities were found, but osteodystrophy was noted in all bones examined histologically. The bone lesions comprised both resorptive and reparative processes. The former was divided into osteocytic and osteoclastic resorption, and the latter originated from the vascular canals. In the early stage, these canals were slightly enlarged with a few osteoclasts, and these dilated spaces became confluent with adjacent lesions in the advanced stage (Fig. 5). Osteocytic resorption, under the influence of swollen osteocytes, caused the bone to become modified and lose its matrix. Consequently, the compact bone became thin and fragile. Usually a reparative process, involving fibrous connective tissue proliferation and osteoid formation, accompanied the resorptive process. Connective tissue proliferated in the marrow cavity and under the endosteum of the compact bone, and the osteoid seams were deposited in a layer on the osseous surface of the bone resorptive areas. Two types of lesions were found in the kidneys:one involved enlarged kidneys with an undulating surface and the other shrunken kidneys with a roughened surface. The former was diagnosed histologically as amyloidosis and the latter as glomerulosclerosis. Renal amyloidosis was observed in nine mice. On the other hand, the parathyroids were enlarged and consisted almost exclusively of chief cells, which were enlarged, closely packed together and oblitered the acinar lobular configuration ; interstitial amyloid deposits were present in nine cases.

Osteodystrophy, similar to the bone lesions found in this study, has been observed in nephrectomized rats [16], elderly rats [17], rats injected with glycopeptide [21], cats on diets with an unbalanced calcium-phosphorous ratio [18] and a dog with chronic interstitial nephritis [3]. I believe that osteodystrophy has not been reported hitherto in mice because of the low incidence and low degree of renal failure in this species. Two types of renal disease, renal amyloidosis and chronic glomerulosclerosis, were observed in mice, and it is obvious that the consequent chronic renal failure induced the secondary hyperparathyroidism and resulting osteodystrophy.

Rat: The form of renal osteodystrophy in rats, which has been studied since the $1970 \mathrm{~s}$ [17], is belived to be caused by hyperparathyroidism arising from chronic nephropathy. However, the bone lesions in affected animals are 
said to occur at the age of 1.5 years or more [15], but the nature of the disease remains unclear. In this study, therefore, I studied the hyperlipidemic rat (HLR), formerly called the spontaneously hypercholesterolemic rat, which shows renal, parathyroid gland and bone lesions from an early age.

A total of 20 male HLRs (5 each at ages $10,14,18$ and 22 weeks) were used in this experiment, and 20 male, age-matched Sprague-Dawley rats were used as controls. The mean serum total cholesterol, triglyceride and phospholipid levels were greater than the respective control levels in 10-week-old rats and increased with age. Furthermore, the mean urea nitrogen, creatinine, inorganic phosphorous and calcium levels were greater than those of the respective control levels from 14 weeks of age. On gross examination of 14-week-old and older rats, the parathyroid gland was enlarged and the kidney was enlarged with an irregular surface in the HLRs compared with the controls, and bone proliferation, osteoblastic hypertrophy, an increase in osteoid seams and an increase in the irregularity of the cement lines were observed histologically. These changes were most severe in the vertebrae, followed, in order, by the sternum, tibia and femur. Furthermore, an increased number of osteoclasts associated with these changes was observed at and after 18 weeks of age. The enlarged parathyroid gland consisted almost exclusively of chief cells showing acinar or lobular configurations, and the changes progresed with increasing age. The kidney showed glomerular sclerotic changes at and after 14 weeks of age, the severity and incidence of which also increased with increasing age.

The HLRs showed osteodystrophy in parallel with the onset of renal failure and hyperparathyroidism from an early age. Therefore, the HLR appears to be a very useful model for studying renal osteodystrophy.

4. Regressive epiphyseal cartilage changes in rats $[42,48]$

There have been no reports describing the morphological changes in the epiphyseal cartilage of laboratory animals. Such regressive changes, which progress with increasing age, were detected in rats.

One hundred and twenty Fischer 344 rats
(Charles River Japan Inc., Kanagawa, Japan) were studied (30 males and 30 females at 7 months of age and 15 males and 15 females at both 13 and 19 months of age). The femur and sternum from each rat were examined, and no gross abnormalities were detected. Upon histological examination, active enchondral ossification was found in the femurs of 7 -month-old rats, with no sex differences. The primary changes were the unmasking and fibrillation of collagen in the matrix, appearance of eosinophilic streaking and necrosis in the epiphyseal cartilage and fissures between the epiphyseal cartilage and trabeculae (Fig. 6 ) . Characteristic disappearance and dissolution of matrix eosinophilic homogeneity with decreased PAS -positive and toluidine blue ( $\mathrm{pH} \mathrm{4.1)-positive}$ substances were observed. These changes extended from the epiphyseal hyalin cartilage zone to the diaphyseal side of the epiphyseal cartilage, and were severe beneath the fissures between the epiphyseal cartilage and trabeculae. As a result of collagen unmasking and fibrillation in the matrix, a few groups of chondrocytes were present. Eosinophilic streaking, which was phosphotungstic acid-hematoxylin positive and stained red with Mallory-azan, appeared in the severely changed parts of the matrix and around the necrotic cartilage. Advanced necrosis in the epiphyseal cartilage was observed in masses or bands with fissures and fibrin exudation. Necrosis sometimes extended from the epiphyseal hyalin cartilage zone to the metaphyseal trabeculae. These degenerative and necrotic changes were first observed at 7 months of age and increased in severity with age (Table 6 ). There was an abnormal proliferation of the epiphyseal hyalin cartilage cells, which extended to the epiphysis, and in some rats, the cartilage mass was observed to be some distance from the epiphysis. In the metaphyses, many trabeculae contained necrotic cartilage, and cleft-like fractures were frequently present between the epiphyseal cartilage and cortex with activation of periosteal osteogenesis. These changes were observed in both anterior and posterior regions. Closure of the epiphyseal cartilage began at 13 months of age and was complete by 19 months of age. Changes in the sternum consisted of unmasking and fibrillation of collagen in the matrix, appearance of eosinophilic streaking and necrosis of the epiphyseal 
Table 6. Incidence and severity of degenerative and necrotic changes in the epiphyseal cartilage of the femur and sternum

\begin{tabular}{|c|c|c|c|c|c|c|c|c|c|c|}
\hline \multirow{2}{*}{ Sex } & \multirow{2}{*}{$\begin{array}{c}\text { Age } \\
\text { (months) }\end{array}$} & \multirow{2}{*}{$\begin{array}{l}\text { Number } \\
\text { examined }\end{array}$} & \multicolumn{4}{|c|}{ Femur } & \multicolumn{4}{|c|}{ Sternum } \\
\hline & & & - & + & H & H & - & + & H & W \\
\hline \multirow{3}{*}{ Male } & 7 & 30 & $0(0)^{\mathrm{a}}$ & $11(37)$ & $19(63)$ & $0(0)$ & $0(0)$ & $18(60)$ & $12(40)$ & $0(0)$ \\
\hline & 13 & 15 & $0(0)$ & $2(13)$ & $8(54)$ & $5(33)$ & $0(0)$ & $6(40)$ & $9(60)$ & $0(0)$ \\
\hline & 19 & 15 & $0(0)$ & $0(0)$ & $2(13)$ & $13(87)$ & $0(0)$ & $2(13)$ & $11(74)$ & $2(13)$ \\
\hline \multirow{3}{*}{ Female } & 7 & 30 & $0(0)$ & $19(63)$ & $11(37)$ & $0(0)$ & $0(0)$ & $20(67)$ & $10(33)$ & $0(0)$ \\
\hline & 13 & 15 & $0(0)$ & $2(13)$ & $13(87)$ & $0(0)$ & $0(0)$ & $3(20)$ & $12(80)$ & $0(0)$ \\
\hline & 19 & 15 & $0(0)$ & $0(0)$ & $10(67)$ & $5(33)$ & $0(0)$ & $4(26)$ & $8(54)$ & $3(20)$ \\
\hline
\end{tabular}

- ; not observed $\quad+$; mild $\quad \#$; moderate $\quad \#$; severe a Number affected $(\%)$

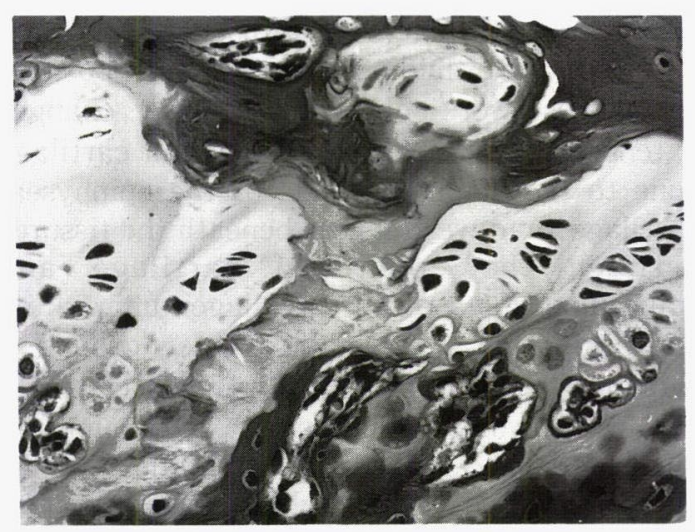

Fig. 6. Femur from a 7-month-old male rat Necrosis of the epiphyseal cartilage with fissure between epiphyseal trabeculae and epiphyseal cartilage HE $\times 200$

cartilage, which was associated with many fissures and fibrin exudation and involved proliferation of fibrocytes, osteoclasts and osteoblasts and formation of osteoids. These sternal changes increased in severity with age in both sexes.

It is suggested that the regressive changes of the femoral and sternal epiphyseal cartilage are caused by mechanical forces, which intensify with age. In addition, mechanical disruption of the epiphseal blood supply at the epiphyseal cartilage-epiphysis junction is considered to be an essential pathogenetic factor. The fact that the regressive epiphyseal cartilage changes were distinct beneath the fissures between the epiphyseal cartilage and trabeculae is suggested to divert or prevent the passage of blood from the epiphyseal vasculature to the cartilage. Furthermore, the epiphyseal cartilage-metaphysis junction is stronger than the epiphyseal cartilage-epiphysis junction in rats, so mechanical force may be placed on the latter parts and lead to regressive changes.

5. Aseptic bone necrosis in mice [45]

Occasional spontaneous aseptic bone necrosis has been described in humans and various animals $[5,7-10,19,20,22,31]$. It has been observed in subjects with traumatic changes and drug-induced or various clinical diseases $[5,8,10,19,22]$. In mice this condition has not been studied thoroughly .

Three-hundred male and 300 female ICR mice (Charles River Japan Inc., Kanagawa, Japan) were kept in a barrier-system animal room and given commercial feed. The tibia and sternum of each mouse were examined. Histologically, aseptic necrosis was found in 23 mice ( 6 males and 17 females) which were used for this experiment. Of these, 3 males died spontaneously at 594-630 days of age, 7 females died at 531-721 days of age and the rest were killed at 728 days of age. On gross examination the articular surface of the tibia was roughened with occasional bone tissue proliferation at the epiphyseal margin. Microscopic changes were present in the epiphysis and diaphysis of the proximal tibial portions. Aseptic necrosis was classified into three types, according to its size and the areas involved. Focal necrosis, which was confined to the epiphysis beneath the articular cartilage, was observed in 3 males and 5 females. In these lesions the marrow tissues had disappeared and been replaced with fibrous and newly formed osseous tissues, and the bone trabeculae were poorly stained, with empty osteocytic lacunae. The areas involved were occasionally affected by 


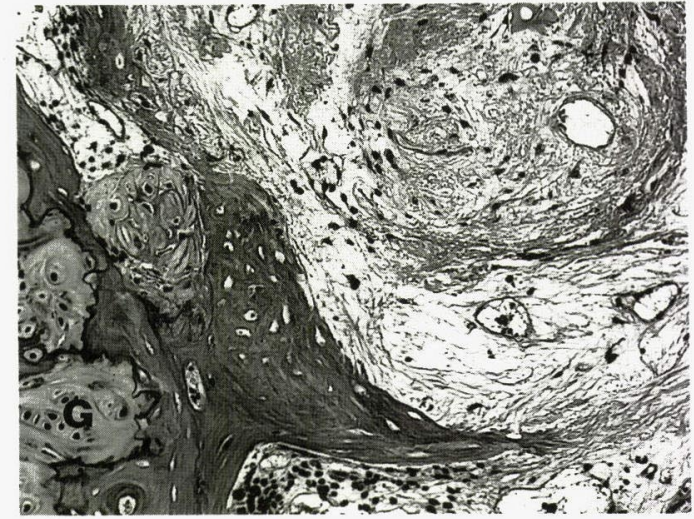

Fig. 7. Tibia from a 671-day-old female rat Exten sive necrosis in the epiphysis $G$ : epiphyseal cartilage $\mathrm{HE} \times 125$

hemorrhages, subchondral trabecular fractures and compressed blood vessels. Most of the animals with focal necrosis had severe degenerative osteoarthrosis involving matrix loosening, erosion, marginal osteophytes in the articular cartilage and eburnation. Extensive aseptic necrosis, in which half to all the epiphysis was involved, was found in 3 males and 11 females. The altered epiphyses showed bone marrow loss and disappearance of the osteocytes from the bone trabeculae (Fig. 7 ) . Transformation of the cellular marrow into soft fibrous tissue and new bone formation occurred simultaneously. Some mice had metaphyseal cortical and cancellous bone fractures and displacement of the growth plate. Degenerative osteoarthrosis, even when the epiphysis was completely necrotic, was not marked. Massive aseptic necrosis in the diaphysis was observed in one female. The lesion had spread through the majority of the diaphyseal areas, but not to the metaphysis. These focal, extensive and massive necrotic areas showed no evidence of any inflammatory reaction, Gram - positive micro-organisms or medullary arterial changes. No sternal aseptic bone necrosis was observed.

Aseptic bone necrosis in association with a number of different processes has been described, although its pathogenesis is diverse and poorly understood [7]. Although the pathogenesis of the focal necrosis beneath the articular cartilage is unclear, a connection with degenerative osteoarthrosis cannot be excluded. It appears likely that continuous mechani- cal or functional stress, which has been suggested to be a major causative factor in degenerative osteoarthrosis, evokes the focal necrosis beneath the articular cartilage, which already is affected by degenerative osteoarthrosis. In addition, the epiphyseal vessel that enters the end of the bone through the ligamentous attachment may be compressed by the osteoarthrotic deformity. Extensive and massive epiphyseal and diaphyseal necroses observed in mice may have been caused by a disturbance of the blood supply. The pathological features of the necroses observed in mice in this study resembled those in young rabbits with infarctions that were induced experimentally by cutting the nutrient artery [2] .

The morphological lesions of bone and cartilage observed in this study should provide useful fundamental background data for toxicological studies and laboratory animal science.

\section{References}

[1] Anderson, M. P. and Capen, C. C. (1978). The endocrine system. In Pathology of Laboratory Animals, pp. 423-508, Benirschke, K., Garner, F. M. and Jones, T. C. (eds.). Springer-Verlarg, New York.

[2] Bragdon, J. H., Foster, L., and Sosman, M. C. (1949). Experimental infarction of bone and marrow . Am. J. Pathol., 25, 709-723.

[3] Brodey, R. S. (1954). Renal osteitis fibrosa cystica in a wire-haired fox terrier. J. Am. Vet. Med. Assoc., 124, 275-278.

[4] Campbell, I. K., Roughley, P. J., and Mort, J. S. (1986). The action of human articular cartilage metalloproteinase on proteoglycan and link protein. Biochem. J ., 237, 117-122.

[5] Cheville, N. F., Cutlip, R. C., and Moon, H. W. (1970). Microscopic pathology of the gray collie syndrome. Pathol. Vet., 7, 225-245

[6] Christman, O. D. (1969). Biochemical aspects of degenerative joint disease. Clin. Orthop., 64, 77-86.

[7] Dogie, C. E., Crowe, S., and Farrow, C. S. (1986) Aseptic necrosis of bone in a dog. Can. Vet. J ., 27, 70-73.

[8] Dubielzig, R. R., Biery, D. N., and Brodey, R. S. (1981). Bone sarcomas associated with multifocal medullary bone infarction in dogs. J. Am. Vet. Med. Assoc., 179, 64-68.

[9] Enlow, D. H. (1966). Osteocyte necrosis in normal bone. J. Dental Res., 45, 213.

[10] Glade, M. J. and Krook, L. (1982). Glucocorticoid -induced inhibition of osteolysis and the development of osteopetrosis, osteonecrosis and osteoporosis Cornell Vet., 72, 76-91.

[11] Greaves, P. (1990). Musculoskeletal system. In Histopathology of Preclinical Toxicity Studies, pp. 143-186, Greaves, P. (ed.), Elsevier, Amsterdam. 
[12] Gustafsson, P. O. and Beling, C. G. (1969) Estradiol-induced changes in beagle pups : Effect of prenatal and postnatal administration. Endocrinology, 85, 481-491.

[13] Howell, D. S. (1975). Degenerative enzymes in osteoarthritic human articular cartilage. Arthritis Rheum. , 18, 167-177.

[14] Ichijo, S. (1966). Pathological studies on the osteorenal syndrome in the dog. Jpn. J. Vet. Sci., 28, 217-228

[15] Iida, M. (1990). Pathology of spontaneously occurring renal osteodystrophy in aged rats. J. Toxicol. Pathol. , 3, 111-123.

[16] Ingalls, T. H., Donaldson, G., and Albright, F. (1943). The locus of action of the parathyroid hormone : Experimental studies with parathyroid extract on normal and nephrectomized rats. J. Clin. Invest., 22, 603-608.

[17] Itakura, C., Iida, M., and Goto, M. (1977). Renal secondary hyperparathyroidism in aged Sprague-Dawley rats. Vet. Pathol., 14, 463-469.

[18] Krook, L., Barrett, R. B., Usui, K., and Wolke, R. E. (1963). Nutritional secondary hyperparathyroidism in the cat. Comell Vet., 53, 224-240.

[19] Ljunggren, G. (1969). Legg-Perthes disease in the dog. Clin. Orthopaedics and Related Res., 62, 31-36.

[20] Merle D'Aubigne, R., Postel, M., Mazabraud, A., Massias, P., and Gueguen, J. (1965). Idiopathic necrosis of the femoral head in adults. J. Bone $J t$. Surg. , 47 B, 612-633.

[21] Nishii, Y., Ono, M., Fukushima, M., Shimizu, T., and Suda, T. (1980). Osseous changes and abnormalities of mineral metabolism in rats with glycopeptide -induced nephritis. Endocrinology, 107, 319-327.

[22] Riser, W. H., Brodey, R. S., and Biery, D. N. (1972). Bone infarctions associated with malignant bone tumors in dogs. J. Am. Vet. Med. Assoc., 160, 411-421.

[23] Sass, B. and Montali, R. J. (1980). Spontaneous fibro-osseous lesions in aging female mice. Lab. Anim. Sci., 30, 907-909.

[24] Silberberg, R., Goto, G., and Silberberg, M. (1958). Degenerative joint disease in castrate mice. Arch Pathol., 65, 438-441.

[25] Silberberg, M. and Silberberg, R. (1941). Age changes of bones and joints in various strains of mice. Am. J. Anat., 68, 69-95.

[26] Silberberg, M. and Silberberg, R. (1950). Effects of a high fat diet on the joints of aging mice. Arch. Pathol., 50, 828-846.

[27] Silberberg, M. and Silberberg, R. (1962). Osteoarthrosis and osteoporosis in senile mice. Gerontologia, 6, 91-101.

[28] Silberberg, M. and Silberberg, R. (1970). Age-linked modification of the effect of estrogen on joints and cortical bone of female mice. Gerontologia, 16, 201-211.

[29] Sokoloff, L. (1959). Osteoarthritis in laboratory animals. Lab. Invest ., 8, 1209-1217.
[30] Sokoloff, L. (1979). Pathology and pathogenesis of osteoarthritis. In Arthritis and Allied Condition, pp. 1133-1189, McCarty, D. J. (ed.), 9 th ed., Lea \& Febiger, Philadelphia.

[31] Sokoloff, L. and Habermann, R. T. (1958). Idiopathic necrosis of bone in small laboratory animals. Arch. Pathol., 65, 323-330.

[32] Sorensen, O. H. and Hindberg, I. (1970). Calcitonin and bone. Lancet, 16, 1061-1062.

[33] Sprinkle, T. A. and Krook, L. (1970). Hip dysplasia, elbow dysplasia, and "eosinophilic panosteitis". Three clinical manifestations of hyperestrinism in the dog? Cornell Vet., 60, 476-490.

[34] Stromberg, P. C. and Vogtsberger, L. M. (1983). Pathology of the mononuclear cell leukemia of Fischer rats. 1. Morphologic studies. Vet. Pathol., 20. 698-708

[35] Trotter, G. W., Mcllwaith, C. W., Norrdin, R. W., and Turner, A. S. (1982). Degenerative joint disease with osteochondrosis of the proximal interphalangeal joint in young horses. J. Am. Vet. Med. Assoc., 180, 1312-1318.

[36] Wase, A. W. ., Solewski, J., Rickes, E., and Seidenberg, J. (1967). Action of thyrocalcitonin on bone Nature, 214, 388-389.

[37] Weisbrode, S. E., Monke, D. R., Dodaro, S. T., and Hull, B. L. (1982). Osteochondrosis, degenerative joint disease, and vertebral osteophytosis in middle-aged bulls. J. Am. Vet. Med. Assoc., 181, 700-705

[38] Yamasaki, K. (1986). Pathology of renal secondary hyperparathyroidism in mice. Exp. Anim ., 35, 93-96.

[39] Yamasaki, K. (1986). Degenerative osteoarthrosis in aged ICR mice. Exp. Anim.. 35, 417-420.

[40] Yamasaki, K. (1991). Early bone lesions in the hyperparathyroidism of hyperlipidemic rats. Exp. Anim., 40, 297-303.

[41] Yamasaki, K., Ikeda, Y., and Itakura, C. (1989). Bone lesions in pig with locomotor dysfunction of hind legs. J. Comp. Pathol., 100, 313-322.

[42] Yamasaki, K. and Inui, S. (1985). Lesions of articular, sternal and growth plate cartilage in rats. Vet. Pathol., 22, 46-50.

[43] Yamasaki, K. and Itakura, C. (1983). Pathology of degenerative osteoarthritis in laying hens. Jpn. J. Vet. Sci., 45, 1-8.

[44] Yamasaki, K. and Itakura, C. (1985). Osteosclerosis in aged ICR mice. Jpn. J. Vet. Sci., 47, 799-802.

[45] Yamasaki, K. and Itakura, C. (1988). Aseptic necrosis of bone in ICR mice. Lab. Anim., 22, 51-53.

[46] Yamasaki, K. and Itakura, C. (1988). Osteosclerosis in F 344/DuCrj rats. Lab. Anim., 22, 141-143.

[47] Yamasaki, K. and Itakura, C. (1988). Bone lesions in clinically normal and in lame pigs. J. Comp. Pathol., 98, 415-432.

[48] Yamasaki, K. and Itakura, C. (1990). Histological and histochemical studies on the articular cartilage and growth plate of rats. J. Toxicol. Pathol., 3, 19-27. 


\title{
実験動物の骨・軟骨における形態学的研究
}

\author{
山崎寛治
}

\author{
財団法人化学品検查協会日田研究所
}

近年, 毒性試験の分野において慢性毒性試験, がん 原性試験が多数実施された結果, 各藏器・器官におけ る変化,さらにはその発生率などが次第に明らかにさ れてきた。しかし骨・軟骨における自然発生病変の病 態さらに発生率についてはほとんど不明であった。そ こでラット，マウスの骨・軟骨について形態学的研究 を行った結果, 变性性骨関節症, 骨硬化症, 堅性骨異 栄養症, 骨端軟骨の退行性変化, 骨無菌性壊死が観察 された。变性性骨関節症：本症はヒトにおいて加秢に より発生する代表的な関節疾患の一つである。しかし 実験動物における自然発生の変化は詳細に報告され ていない。今回 Sprague-Dawley ラットの大腿骨, 滕 蓋骨を検索した結果，すでに 6 力月㱓より関節軟骨の 基質に変性を示すものがみられ，さらに 12 月粭では 軟骨の変性・壊死，関節軟骨縁での軟骨增殖，糜爛が 出現していた。また組織化学的検索の結果, 本症の発 生, 進展については軟骨基質におけるグリコスアミノ グリカンの変化が重要であると考えられた。一方, ICR マウスの脛骨においても関節軟骨基質の変性, 軟骨の 変性・壊死，関節軟骨縁での骨增殖，糜爛，さらに関 節軟骨下での骨硬化性変化が観察され，それらは加秢 に伴い重度となっていた。これら動物の変性性骨関節 症は七トにおける本症の病因論及び発生機序の解明 に寄与するものと思われた。骨硬化症：6，18，30力 月齢の Fischer 344 ラットの脛骨，胸骨を検索した結 果, 雌雄共に 6 力月鮯から骨觬胿に骨質の増加が観察 され，30力月鮯では骨髄胿は層板形成を示寸新生骨で 置換されていた。また変化は雄に比較し雌で重度で あった。一方, ICR マウスの脛骨, 胸骨では, 雌で 300 日粭以降, 雄で 350 日粭以降に骨硬化症が高率に観察 された。変化の程度としては雄に比較し雌で重度で
あったが，730日秢までの発生率に雌雄間の差はみら れなかった。また変化はラットと異なり多数の造骨性 細胞, 骨芽細胞の増殖さらには破骨細胞の出現で始ま り，結果として骨質は増加していた。堅性骨異栄養 症：マウスにおける本症の詳細な報告はなされてい ない。雌雄各 370 例の ICR マウスを検索した結果, 雄 で 300 日秢以降の 8 例, 雌では 450 日粭以降の 11 例 に腎性骨異栄養症が観察された。マウスにおける本症 の発生率はすでに報告されているラットのものに比 較し低率であったが, 骨の変化は本質的に同一であっ た。一方, ラットでの本症はヒトの堅性骨異栄養症の モデルとして問題になってきた。しかし，その発生が 高率化するのは生後 1.5 年以降からという時間的問 題のため研究に支障を来してきた。今回早期から堅系 球体硬化症を示す高脂血症ラットを検索した結果, 14 週粭から腎性骨異栄養症が観察された。この結果から 高脂血症ラットは本症の疾患モデル動物になること が示唆された。骨端軟骨の退行性変化：Fischer 344 ラットの大腿骨, 胸骨を検索した結果, 雌雄共に 7 力 月粭より骨端軟骨の変性・壊死が観察され、加龄に伴 い重度化していた。本症の発生原因としては骨端軟骨 に対する物理的圧力が考えられた。骨無菌性壊死： ICR マウス雌雄各 300 例を検索した結果, 雄 6 例, 雌 17 例の脛骨に無菌性壊死が観察された。变化は関節 軟骨下に限局するもの，骨端全体さらには骨幹に広域 に及ぶものに分類された。発生原因としては血管障害 が推測された。以上の骨・軟骨における形態学的研究 の成果は, ラット，マウスを用いる化学物質の骨・軟 骨に対する毒性学的研究あるいは実験動物学の基礎 的資料として有用であると考えられた。 